\title{
Transport service quality and perceived service value: an international comparative survey in European and Indian context
}

\author{
Naveen Bangalore Ramu* and Anjula Gurtoo \\ Department of Management Studies, \\ Indian Institute of Science, \\ Bengaluru 560012, India \\ Email: naveen.b.ramu@gmail.com \\ Email: anjula@iisc.ac.in \\ *Corresponding author
}

\begin{abstract}
Road transportation plays a critical role as a means to commute between places. Ensuring quality in this service, therefore, is crucial. In this paper, we explore the service quality characteristics of intercity bus passenger transport and analyse the determinants of commuters' perceived service value in the European and Indian context. A structured questionnaire was administered face-to-face and captured the passengers' perception of service quality. Factor analysis and multiple linear regression were used to test the research hypotheses of the study. Empirical results demonstrate that timely service, women-friendliness, ticket price affordability and service to price satisfaction are common to passengers from Europe and India, and significantly impact commuters' perceived service value devised as overall satisfaction. In particular, external tangibles such as clean drinking water, clean bus stops are however significantly more important for passengers in Europe, while handling of luggage is a more appropriate tangible for passengers in the Indian context. Additional analysis suggests that technology also significantly impacts the overall satisfaction of passengers in both contexts. Several comparative results were discussed for their context similarities and differences.
\end{abstract}

Keywords: service quality; perceived service value; intercity bus transport; public transport; transport policy; bus transport; international comparative study.

Reference to this paper should be made as follows: Ramu, N.B. and Gurtoo, A. (2019) 'Transport service quality and perceived service value: an international comparative survey in European and Indian context', Int. J. Comparative Management, Vol. 2, No. 1, pp.7-32.

Biographical notes: Naveen Bangalore Ramu is a Postdoctoral Research Fellow at the Department of Management Studies, Indian Institute of Science, Bengaluru. He received his $\mathrm{PhD}$ in the field of Public Transport from Indian Institute of Science, Bengaluru. His research interests are mainly in the fields of public transport, service quality, customer satisfaction and sustainable livelihood.

Anjula Gurtoo is the Chairman of Centre for Society and Policy (CSP), at Indian Institute of Science, Bengaluru. She is a Professor at the Department of Management Studies, Indian Institute of Science, Bengaluru. Her teaching and research activities are mainly in the fields of equity issues in governance; sectoral reforms; informal economy; informal entrepreneurship; public 
participation and empowerment; infrastructure and development; and environment, citizenship and group behaviour. Her research has been published in international journals of repute, such as Journal of Sociology and Social Policy, Asian Social Work and Policy Review, International Entrepreneurship and Small Business, Developmental Entrepreneurship, Asian Public Policy, Economic Policy and Research, and among others.

\section{Introduction}

The mobility of a passenger or a commodity from a particular origin to a destination for a specific time period is termed as transportation (Winston, 1985). Public transportation is the continuing transportation or special conveyance to the public through various modes such as buses, subways, rail, trolleys and ferry boats. Although intercity transport represents only $2 \%-10 \%$ of the total trips, it occupies $30 \%-45 \%$ of global passenger-kilometres (Bak et al., 2012; Hayashi et al., 2014).

A greater part of society recognises that transportation is an essential service, and the government plays a vital and unavoidable influence on this service (Winston, 1985). A proficient transport network builds profitability and upgrades the competitive efficiency of the economy (Namboodiri, 2007). The research on service quality attributes of transport, however, is inadequate. Although intercity transport activity has greater impact and reach but is eclipsed by urban transport research. However, growth projections demonstrate that travel between cities will rise in the future. Hence bringing in superior quality connectivity between intercity and urban transport becomes important (Allard and Moura, 2018).

In this paper, we explore the nature of intercity bus passenger transportation in the European context and the Indian context. Therefore, research questions are as follows:

R1 What are the basic service quality factors of intercity bus passenger transportation in European and Indian contexts?

R2 What are the determinants of perceived service value/satisfaction in both contexts?

R3 How technology does moderate the relationship between transport service quality factors and commuters' overall satisfaction in both contexts?

The sample size for the Indian context and the Europe context are 605 and 50, respectively. Since the data points in the two contexts differ substantially, bootstrapping is employed for both data to develop 3,000 samples each for both contexts.

According to the report of the International Road Transport Union, the second most preferred transport mode in Europe are buses and coaches after passenger vehicles (Rohani et al., 2013). In several countries of Europe, coaches are operated on a commercial basis (Rohani et al., 2013). According to Eurostat data, 9.2\% of inland passenger transport is accounted by buses and coaches whereas $7.4 \%$ is accounted by trains in EU-28 by 2013 (ILO, 2015). The fare system of this mode appealing to young, older, lower income groups and people without access to a car (ILO, 2015). Buses and coaches usually fulfil the transport needs of less wealthy citizens in the countries like Canada, the European Union and the USA whereas services range from no frills to luxury first class buses in low and middle-income countries (ILO, 2015). 
In India's comprehensive surface transport network, intercity bus transportation holds an important place because of the potential in connecting cities, smaller communities, rural areas and less populated regions (Fravel, 2003). Higher economic growth, large scale development of national highways which link Indian cities and relatively lesser growth in Indian railways makes intercity bus transport services important and equally essential in India (Clean Air Asia Center, 2012).

Two reasons compel us to study the two contexts in their service quality factors and overall satisfaction:

a Does India's low transport infrastructure and Europe's better transport infrastructure make a difference in transport service quality?

b Are there differences among commuters' perceived service value/overall satisfaction? If yes, do institutional and cultural differences play a role?

Because the composition of a population affects passengers' satisfaction level (Ponrahono et al., 2016) and perceptions vary with culture, for example, in the case of British and French viewers' responses to commercial advertisements (Bremser et al., 2018). Preferences, values and needs of individuals change over time and vary among groups and cultures (Steg and Gifford, 2005). Further, the influence of stakeholders will differ across cultures (Lamb and Roundy, 2018).

This study contributes to the transport and public sector management literature in two ways. First, external tangibles such as clean drinking water, clean bus stops are more important to passengers in the European context than in the Indian context. Handling of luggage on the other hand is given more importance by the passengers in the Indian context as compared to the European context. This highlights the cultural differences between the two regions. Second, the study highlights how technology changes the determinants of overall satisfaction. We find environmental and external tangibles become significant to overall satisfaction whereas tangibles become insignificant in the European context. The variance of the model is increased when technology is introduced in both European and Indian context. In other words, technology has a greater influence on overall satisfaction in the European context compared to the Indian context.

The remainder of the paper is organised as follows. Section 2 presents a review of the literature and hypotheses development; Section 3 explains sampling and questionnaire instrument; Sections 4 and 5 shows extensive comparative results and additional analysis output respectively; Section 6 discusses key findings of the study and test of the hypotheses; Section 7 concludes the study.

\section{Literature review and hypotheses development}

\subsection{Comparison between Europe and India}

Adhering to standard code of practice for bus design and services is mandatory for the transport service providers in developed countries (Echeverry et al., 2005; Estache and Gómez-Lobo, 2005; Finn and Mulley, 2011). Therefore, the passenger dissatisfaction with respect to bus design quality is not as apparent as compared to developing countries (Das and Pandit, 2016). Physical facilities such as comfort, cleanliness, waiting time, safety, aesthetics of bus, interior of bus and adequate maintenance are considered basic 
service quality dimensions (Parasuraman et al., 1988; Herrmann et al., 2000; Lu and Ling, 2008; Carreira et al., 2013). The service attributes of public transport such as stops and terminals, transport points and vehicles also contribute to passengers' evaluation of service quality (Tyrinopoulos and Antoniou, 2008).

In Europe, environmentally friendly buses with affordable tickets, comfort seats and free Wi-fi make road public transport competitive with other modes of transports (Soloviev, 2015). The safety and high standards of buses in Germany are guaranteed by the inspections for every two years by Technical Inspection Association (TÜV) of Germany.

According to German Statistical Federal Office, the safest way to travel on Europe's roads is by bus. Many bus transport service providers in Europe are upgrading the equipment of their buses to enhance safety, security and comfort of passengers along with the regular health check to avoid bad habits such as drug intoxication, alcohol and lack of sleep (Soloviev, 2015). Adding to this, the regulations and policies transportation infrastructure are playing an important role for low fatal rate in Europe, where most of them are obligatory and some are voluntary which ensures high safety level. Technical attributes are enabling drivers to forecast the danger situations or directly participate in a save driving process (Soloviev, 2015).

According to the National Highways Authority of India (NHAI), India constitutes 3.3 million $\mathrm{km}$ of total road length while the share of national highways is only two per cent of the overall road network but still they carry about $40 \%$ of the total road traffic. The potential for surface transport is huge with the improvement in overall road connectivity. Since intercity transportation involves connecting cities, rural-urban areas and which has large transportation distance and most of the intercity public transport happens on national and state highways and because of this, quality of road infrastructure influences the quality of intercity bus passenger transport services.

In India, technology is being introduced rapidly. E-tickets are considered valid proof or ticket in the bus transport. Electronic ticketing systems such as online ticket buying websites, e-ticket teller machines and bus pass are introduced to minimise the passenger queues, waiting times and enhance service delivery time (Sam et al., 2018). Buses and coaches usually fulfil the transport needs of less wealthy citizens in the countries like Canada, the European Union and the USA whereas services range from no frills to luxury first class buses in low and middle-income countries (ILO, 2015).

However, poor economic profiles of transport users in developing countries is one of the reasons for service delivery compromises and poor service levels and bus design, to maintain the low fares (Andaleeb et al., 2007; Susilo et al., 2010; Kaushik, 2015). Ponnaluri (2011) suggests that providing high quality services should be the core theme of India's transport systems development strategy. Mobility and accessibility have increased in India over the years but there are critical issues like, delays, accidents and congestion leading to service quality. Safe and comfortable access to bus stations and intermodal integration are also equally essential in transportation infrastructure because lack of access to bus stops should not discourage passengers to use public transport (Clean Air Asia Center, 2012). 
Transport service quality and perceived service value

Table 1 Summary of key findings from cross-country researches on transport service quality

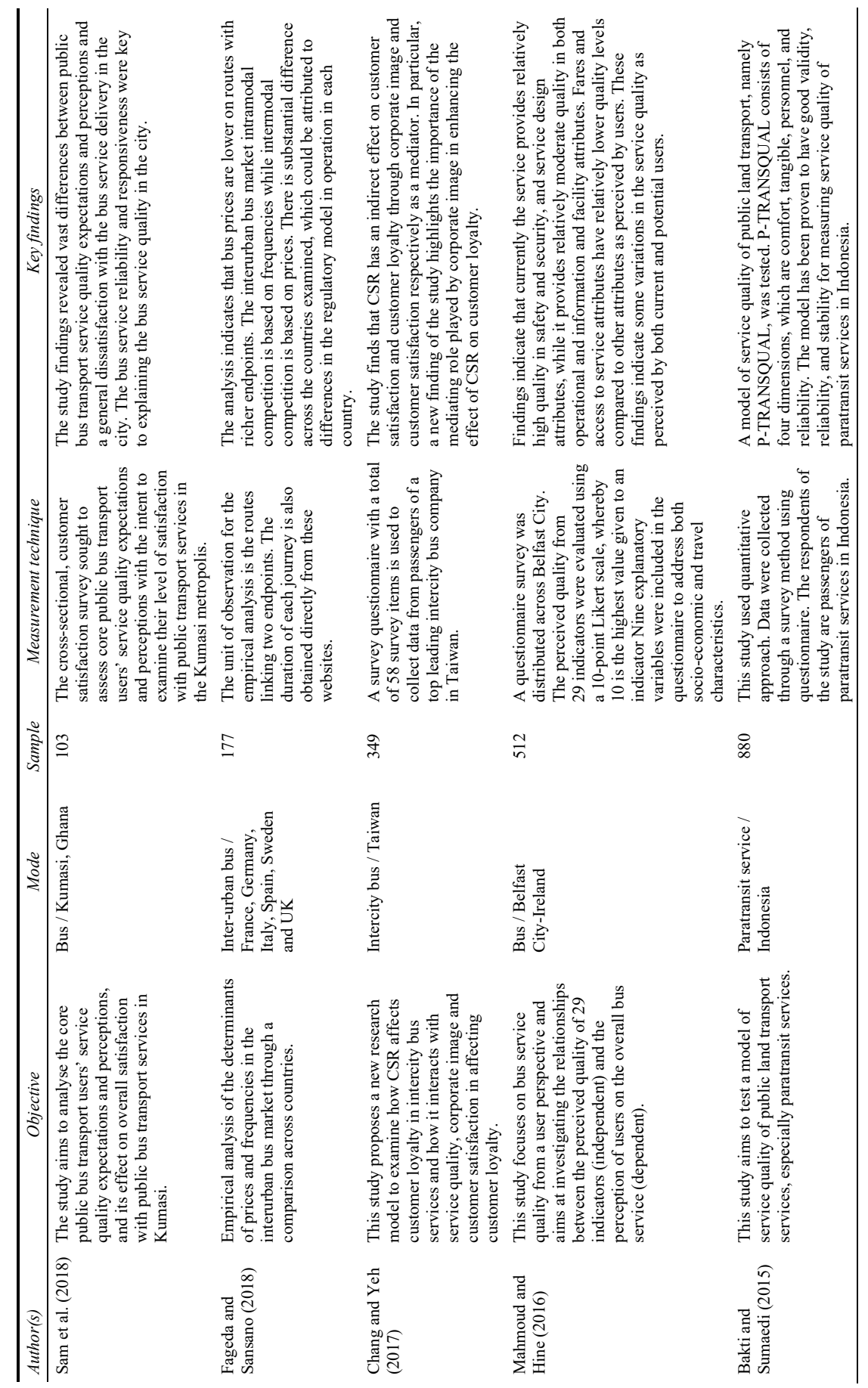


Table 1 Summary of key findings from cross-country researches on transport service quality (continued)

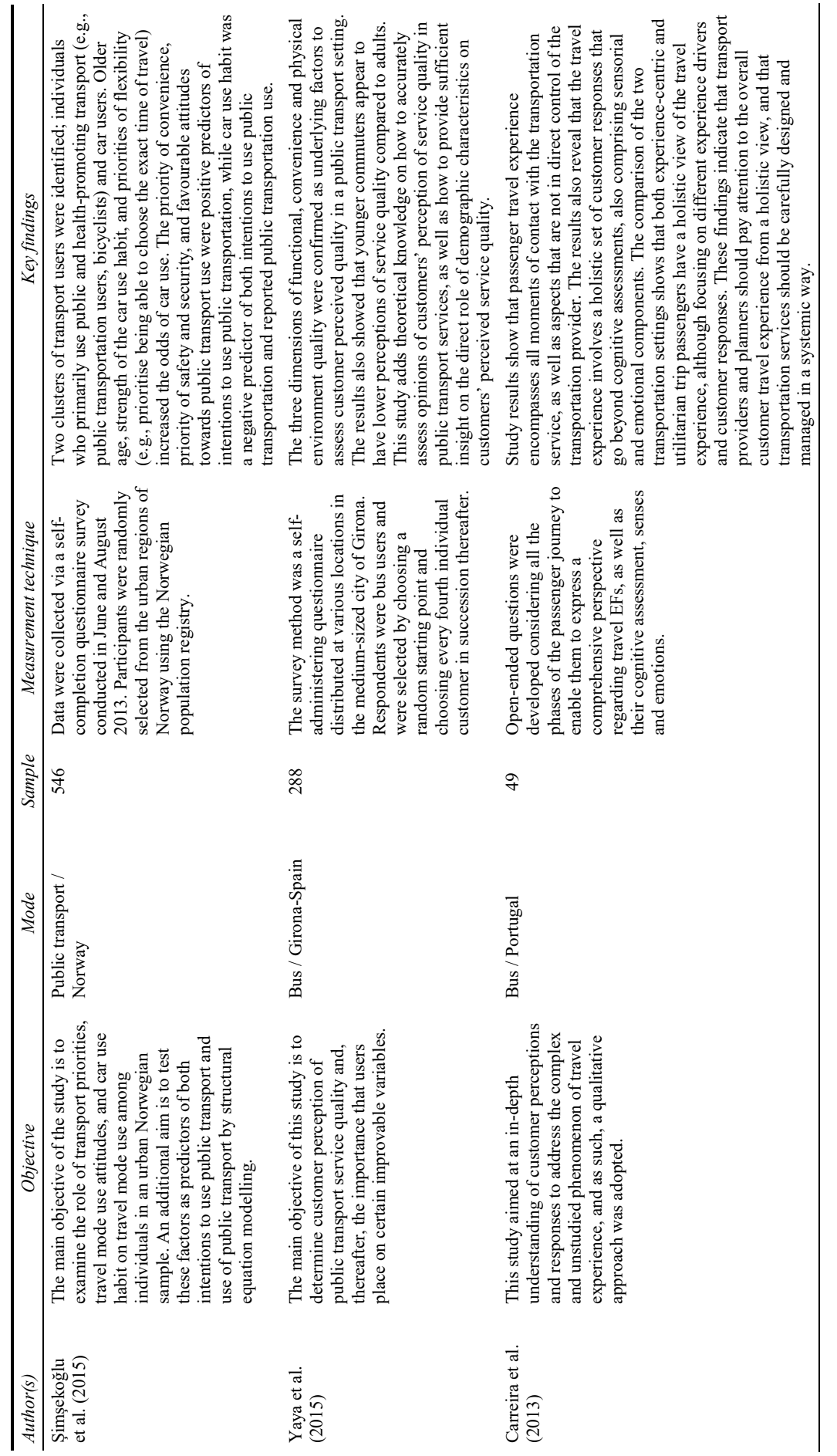


Table 1 Summary of key findings from cross-country researches on transport service quality (continued)

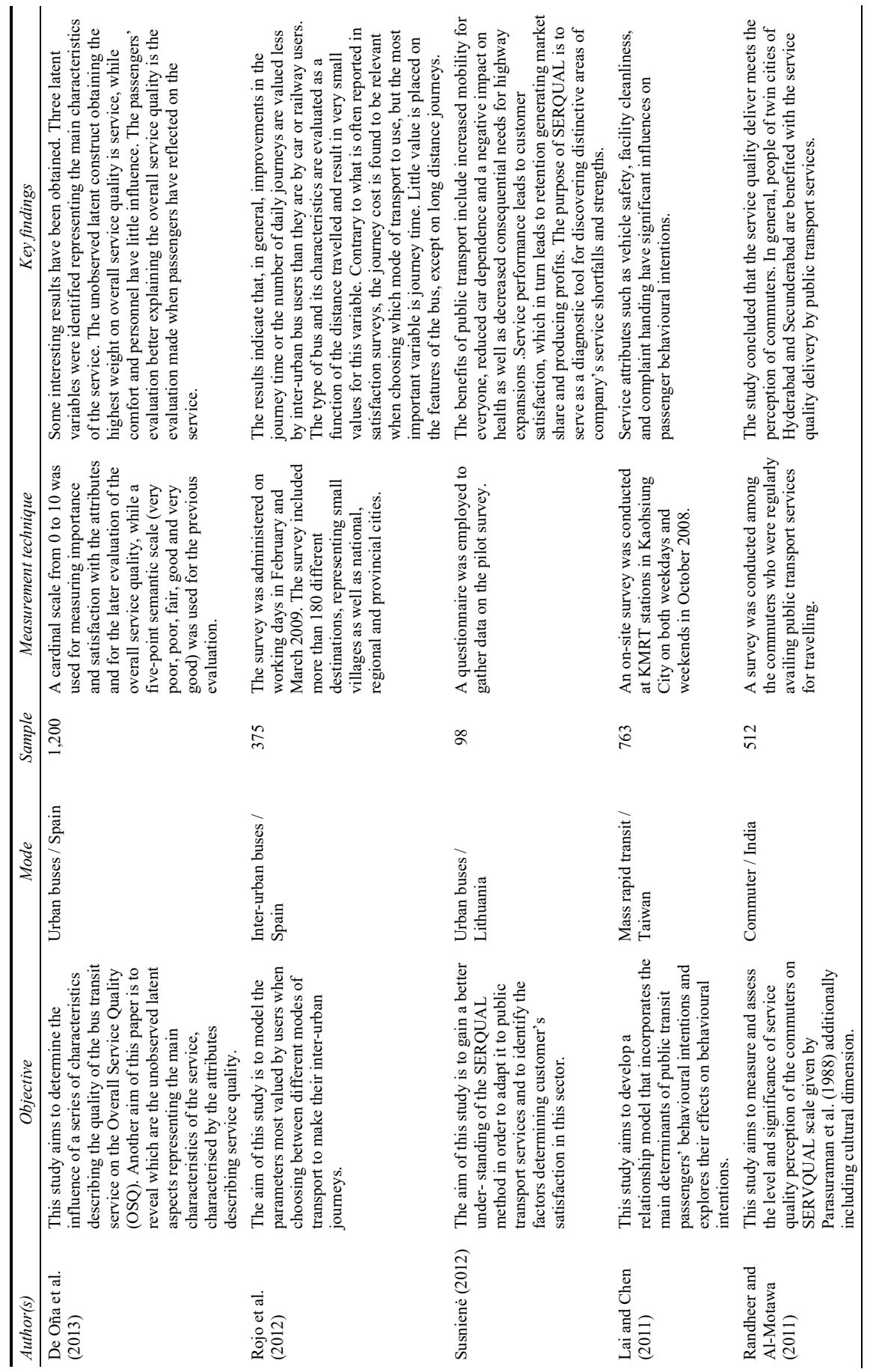


Table 1 Summary of key findings from cross-country researches on transport service quality (continued)

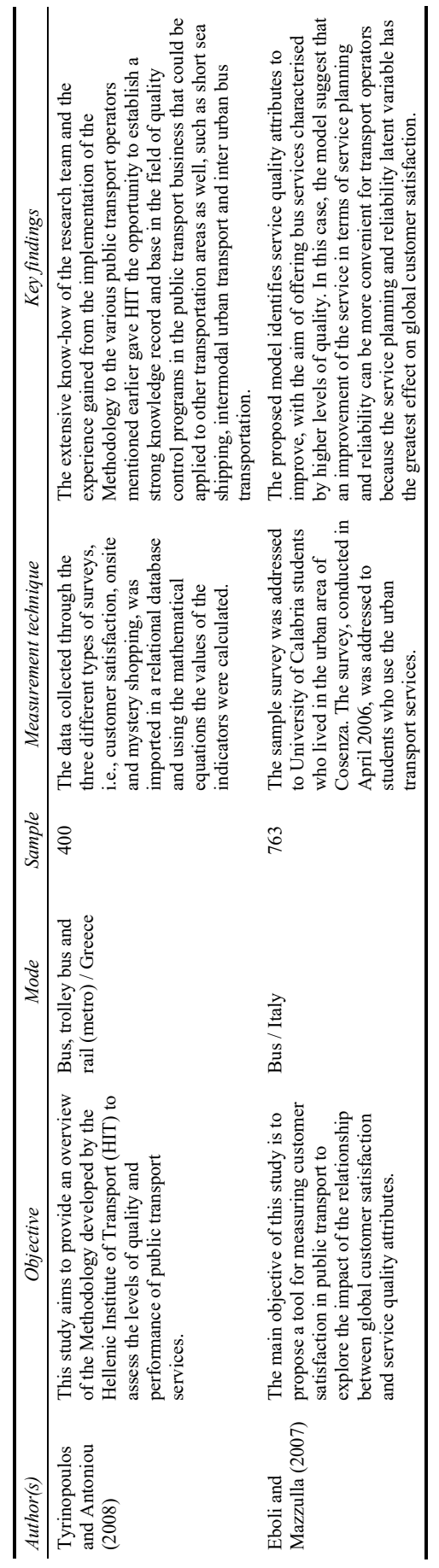




\subsection{A review of the literature and research gaps}

Based on constructive suggestions for conducting a literature review and developing research hypotheses, we objectively survey several research articles published in various management and engineering journals. For brevity, we present some important findings of cross-country researches that explore transport service quality and commuters' overall satisfaction (see Table 1). Yet, there is a dearth of comparative studies in the case of intercity bus transport service and this paper, hence, is the first international comparative survey of European and Indian commuters in transport and public sector management literature. From the literature, it is evident that intercity bus transport is well defined and organised in the European context compared to Indian counterpart. This study is a unique attempt to analyse service quality and perceived service value dimensions of intercity bus transportation in India and Europe. This helps in understanding the nature of intercity bus transportation in both the contexts and provides an opportunity for learning good public governance practices.

\subsection{Hypothesis development}

\subsubsection{Service quality}

Bitner and Hubbert (1994) define service quality as the impression of relative superiority or inferiority by the customers. Public transport is considered a service for demonstrating characteristics similar to a service (Irtema et al., 2018). According to Zeithaml (1988), consumer's subjective view regarding the supremacy or superiority of a product or service gets reflected in the perceived quality.

Cronin and Taylor (1992) introduced the SERVPERF model with the argument that service quality should be measured as an attitude and reinforced the perception-based measurement of service quality. In support of the above, other service quality researchers argue that service quality should be measured through customer perception of service (Gagliano and Hathcote, 1994; LeBlanc and Nguyen, 1997; Nagata et al., 2004; Hu and Jen, 2006; Clemes et al., 2008;). Adding to these arguments, variation in service quality measurement was explained by SERVPERF by using the model in four service industries of fast food services, banks, pest control and dry cleaning (Leong et al., 2015). This paper uses the theoretical model of SERVPERF to study the research objectives.

\subsubsection{Service quality features}

The three distinctive characteristics of service quality identified by Horovitz (1986) are as follows:

- $\quad$ customer consumes the services at the same time as they are produced

- $\quad$ service is predominantly an 'experience' although it is made up of a set of benefits

- healthy relationship between the service provider and the consumer is an essential aspect of service quality.

According to Namboodiri (2007), benchmark for service quality measurement of bus transport includes reliability of buses, information provided to the passengers, perceived service quality by passengers, bus cleanliness and issue redressal. As per the findings of 
Yaya et al. (2015) study, intercity passengers compare the characteristics of each mode such as fare, travel time, access to stations and airports, comfort and frequency before making choices. Lardinois (1989) shows that prices and other transportation service attributes, such as frequencies, travel times, schedules, vehicle comfort and congestion effects impact service quality. Providing a good accessibility resulting in safe, reliable, convenience, intelligent, and effectiveness of transportation system is one of the prerequisites for a public bus service (Aghdaie and Faghani, 2012). In road transport, employee's courtesy attributes such as respect, politeness, consideration and friendliness play an important role as service quality features (Parasuraman et al., 1985). According to Wen et al. (2005), indicators such as willingness to help, employee responsiveness, empathetic to passenger needs and employee courtesy represents the crew attitude which is one of the dimensions of intercity bus service quality. In the case of intercity bus passengers travelling longer distances, allowable vibration exposure time with respect to oscillatory comfort has a significant importance (Sekulić et al., 2018).

\subsubsection{Satisfaction}

Service quality is considered as a medium of achieving customer satisfaction and they both are conceptualised as explicit but closely connected entities in marketing literature (Beerli et al., 2004; Chen, 2008; Chou and Kim, 2009; Siddiqi, 2011). User satisfaction can be improved by emphasising on perceived value and service quality (Irtema et al., 2018). Service quality is positively related to customer satisfaction in the context of public transport (Khurshid et al., 2012). Satisfaction in the passenger's perception is determined by the cost, travel distance, purpose and frequency (Ponrahono et al., 2016). This is due to the difference between socio-demographics and characteristics of trip which influences the satisfaction level of the passengers (Ponrahono et al., 2016).

Consumption of service and purchasing decision can be used to determine the customer satisfaction (Chang and Yeh, 2017). For the services which are considered as necessities, user satisfaction is a key indicator of public service quality (Chica-Olmo et al., 2018). Customer satisfaction is seen through strengthening and improving service traits such as frequency, cleanliness and reliability (Irtema et al., 2018). The overall evaluation of total purchase and experience gained from the consumption is said to be the satisfaction for the intercity bus passengers (Anderson et al., 2004). Passengers' expectations, perception on service providers, perceived service quality and perceived price quality have significant influence in shaping passenger satisfaction (Fornell, 1992).

Based on the aforementioned contextual differences, literature review and theoretical perspectives, the following hypotheses are developed:

H1 Institutional and cultural differences exist between Europe and India with respect to the intercity bus transport service quality.

H2 Transport service quality will have a positive impact on commuters' perceived service value in Europe and Indian contexts and this positive effect significantly differs. 


\section{Methodology}

\subsection{Sampling}

According to Karnataka State Road Transport Corporation (KSRTC) Key Statistics 2015, on an average 26.90 lakh passengers travel every day. By considering 26.90 lakh as the population, with $95 \%$ confidence level and $4 \%$ margin of error, the sample size for passenger questionnaire is 600. The survey was conducted between August 2016 and March 2017 at the intercity bus stations mainly in the Bangalore region, through convenience sampling technique. In the demographic distribution, majority of Indian respondents are 15-30 years of age group, are students and males have post graduate qualification. Majority of the passengers have monthly income is between INR 5,000 to 10,000 . In the journey distribution, majority of the passengers travelled in government buses which are non-AC normal and travelled for more than 350 kilometres with travel time more than eight hours with the route having both hilly and plain routes. Majority of the passengers spent around 15 to 30 minutes of time in traffic in their journey, are occasional travellers and have chosen the same bus service provider for two to five times in their previous intercity travel. With respect to policy attributes, most of the buses had fire exit, first aid box, no entertainment opportunities and no seat belts. Majority of respondents agreed that seat belt in buses and inspection by officials improves the safety and expressed their opinion in making seat belt mandatory.

The European survey was conducted in February 2017 at the intercity bus stations in the European countries of France, Germany and Netherlands, and 51 passengers responded to the survey. Majority of the respondents are below 35 years of age and had travelled in private buses in Europe. Most of them travelled more than $350 \mathrm{kms}$ and in $\mathrm{AC}$ semi sleeper buses. Regarding the improving of service quality by inspection of officials most of them agree that inspection by officials will improve the intercity bus service quality, and that seat belt should be made mandatory and improve the safety. Majority of respondents opined that graduated driver license should be practiced for responsible and informed driving.

Study with larger sample is done in the Indian context whereas smaller sample is considered in the European context due to survey constraints. European study can be used as a case study, but bootstrapping technique is used to compare the service quality of intercity bus service in both the contexts. In India, intercity buses originating from Bangalore region is considered whereas in Europe, buses originating from Amsterdam, Berlin and Paris are considered due to geographical constraints. The rationale behind considering three regions in the Europe is that these regions allow considerable journey time and distance for the passengers to experience the intercity bus journey.

\subsection{Questionnaire}

Dimensions and items of reliability, assurance, tangibility, empathy, and responsiveness (RATER) are adopted from SERVPERF (Cronin and Taylor, 1992) which is well established and widely accepted service quality measuring instrument in measuring perceived service quality (Leong et al., 2015). Intercity bus transport passengers form the 
population for this study. Pilot study is conducted for totally 35 respondents and survey was administered face to face. Initial questionnaire had 134 items. After the pilot study necessary changes are made to the questionnaire with find items being 141. Most of the variables are continuous since questionnaire captures perceptions about service quality (Appendixes 3-4).

The questionnaire piloted and tested in India is implemented for survey in the Europe as well. The sample size in Indian context is 605 and European context is 51. Data employs hierarchical regression with bootstrapping to explore the relationship of service quality factors with overall satisfaction of intercity bus transport in both the contexts. Bootstrapping is a useful technique for testing model stability and estimates the sampling distribution of an estimator by resampling with replacement from the original sample. Bootstrapping is one method to assess a statistic computed from a sample and temporarily substitute the empirical probability distribution induced by the sample for the probability distribution defined by the population. It is a method for deriving robust estimates of standard errors and confidence intervals for estimates and increasing sample size makes the error smaller. The bootstrap principle says that choosing a random sample of size $\mathrm{n}$ from the population can be mimicked by choosing a bootstrap sample of size $\mathrm{n}$ from the original sample. 3,000 samples for bootstrapping are chosen to represent the population well enough to mitigate outliers and anomalies that can degrade the accuracy or applicability of analysis. 3,000 samples result in minimum error and beyond which there was no beneficial effect.

\subsection{Data analysis}

Factor analysis explores the basic factors of service quality of intercity bus transport in both European and Indian context. Reliability analysis namely, Cronbach's alpha test validates the explored service quality constructs. Hierarchical regression with bootstrapping explores the determinants of service quality satisfaction in both European and Indian contexts. Hierarchical regression technique studies the change in the relationship between service quality factors and overall satisfaction when technology factor is included in the model. Note that profile of respondents was not presented in light of the privacy and security concerns promised at the time of survey in both contexts.

\section{Results}

\subsection{Service quality factors: European context}

The service quality variables are subjected to factor analysis in the SPSS software. First, the Kaeser-Meyer-Olkin (KMO) and Bartlett's sphericity tests are conducted to assess the sampling adequacy and the strength of relationship among the variables respectively (Table 2). Kaeser (1974) recommended the threshold value of KMO as 0.5 to conduct satisfactory factor analysis. Bartlett's test of sphericity is significant at less than 0.05 to reject the hypothesis of correlation matrix being an identity matrix. These two tests pave the way to conduct the factor analysis. 
Table 2 KMO and Bartlett's test: dimensions of service quality

\begin{tabular}{lcc}
\hline \multicolumn{3}{c}{ KMO and Bartlett's test } \\
\hline Kaiser-Meyer-Olkin measure of sampling adequacy & .659 \\
\hline Bartlett's test of sphericity & Approx. chi-square & $1,628.314$ \\
& df & 378 \\
& Sig. & $0.000^{* *}$ \\
\hline
\end{tabular}

Note: $* * \mathrm{p}<0.01 ; * \mathrm{p}<0.05$

Table 3 Reliability analysis and factor loadings of survey instrument (European context)

\begin{tabular}{|c|c|c|c|c|}
\hline Sl. no. & Construct & Items & Factor & Cronbach \\
\hline \multirow[t]{11}{*}{1} & \multirow[t]{11}{*}{ Reliability } & Clean bus & 0.868 & \multirow[t]{11}{*}{0.949} \\
\hline & & Employees tidiness & 0.826 & \\
\hline & & Good seats in bus & 0.789 & \\
\hline & & Women friendly & 0.785 & \\
\hline & & Women safety and security & 0.778 & \\
\hline & & Safety precaution information & 0.769 & \\
\hline & & Pleasant interiors & 0.751 & \\
\hline & & Ticket price affordability & 0.750 & \\
\hline & & Clean bus stops & 0.737 & \\
\hline & & AC working & 0.718 & \\
\hline & & On time departure and arrival & 0.673 & \\
\hline \multirow[t]{4}{*}{2} & \multirow[t]{4}{*}{ Responsiveness } & Necessary intervals & 0.847 & \multirow[t]{4}{*}{0.804} \\
\hline & & Employees responsiveness & 0.829 & \\
\hline & & Luggage carrying & 0.586 & \\
\hline & & Luggage place & 0.502 & \\
\hline \multirow[t]{3}{*}{3} & \multirow[t]{3}{*}{ Environment } & Abnormal vibration & 0.929 & \multirow[t]{3}{*}{0.940} \\
\hline & & Air pollution & 0.913 & \\
\hline & & Noise pollution & 0.890 & \\
\hline \multirow[t]{2}{*}{4} & \multirow[t]{2}{*}{ Empathy } & Information announcement at stops & 0.943 & \multirow[t]{2}{*}{0.977} \\
\hline & & Individual attention & 0.936 & \\
\hline \multirow[t]{2}{*}{5} & \multirow[t]{2}{*}{ Tangibles } & Clean toilets & 0.760 & \multirow[t]{2}{*}{0.798} \\
\hline & & Sufficient poles & 0.745 & \\
\hline \multirow[t]{2}{*}{6} & \multirow[t]{2}{*}{ Assurance } & Information on bus & 0.903 & \multirow[t]{2}{*}{0.713} \\
\hline & & Sufficient buses & 0.759 & \\
\hline \multirow[t]{2}{*}{7} & \multirow{2}{*}{$\begin{array}{l}\text { External } \\
\text { tangibles }\end{array}$} & Clean drinking water & 0.797 & \multirow[t]{2}{*}{0.527} \\
\hline & & Eateries at stops & 0.700 & \\
\hline
\end{tabular}


Seven components are extracted from the factor analysis whose eigenvalues are greater than 1. These ten factors cumulatively add up to $82.56 \%$ of variance in the service quality variables as shown in the Table 2 . After the extraction of seven factors, we rotate the obtained factor structure to reduce the number of factors, to create a simple structure for interpretation.

The varimax rotation results in fseven orthogonal factors (Appendix 1). Factor 1 represents reliability; 2 represents responsiveness; 3 represents environment; 4 represents empathy; 5 represents tangibles; 6 represents assurance; 7 represents external tangibles. The factor loadings which correspond to the individual contribution of a variable in the factor or component are presented in the Table 3, along with reliability analysis using Cronbach's alpha. Higher the factor loading, more is the correlation between the observed variable and the latent factor.

\subsection{Service quality factors: Indian context}

The Kaeser-Meyer-Olkin (KMO) and Bartlett's sphericity tests are conducted to assess the sampling adequacy and the strength of relationship among the variables respectively (Table 4). These two tests pave the way to conduct further analysis and explore underlying factors.

Table 4 KMO and Bartlett's test: dimensions of service quality (Indian context)

\begin{tabular}{lcc}
\hline \multicolumn{3}{c}{ KMO and Bartlett's test } \\
\hline Kaiser-Meyer-Olkin measure of sampling adequacy & 0.804 \\
\hline Bartlett's test of sphericity & Approx. chi-square & $8,275.518$ \\
& df & 528 \\
& Sig. & $0.000 * *$ \\
\hline
\end{tabular}

Note: $* * \mathrm{p}<0.01 ; * \mathrm{p}<0.05$.

A total of ten components are extracted whose eigenvalues are greater than 1 . These ten factors cumulatively add up to $62.15 \%$ of variance in the service quality variables as shown in Appendix 2. The factor loadings which correspond to the individual contribution of a variable in the factor/component are presented in the Table 5. Higher the factor loading, more is the correlation between the observed variable and the latent factor.

The Cronbach's alpha values, for reliability of all the service quality constructs are around 0.6 to 0.8 which is considered as a threshold value and hence there is an internal consistency in service quality measures. The Cronbach's alpha value of satisfaction construct is 0.613 which is considered acceptable by researchers. The constructs, corresponding items and Cronbach's alpha value are presented in Table 5. 
Table 5 Reliability analysis and factor loadings of survey instrument (Indian context)

\begin{tabular}{|c|c|c|c|c|}
\hline Sl. no. & Construct & Items & Factor & Cronbach \\
\hline \multirow[t]{2}{*}{1} & \multirow{2}{*}{$\begin{array}{l}\text { Service time } \\
\text { reliability }\end{array}$} & On time arrival & 0.774 & 0.698 \\
\hline & & On time departure & 0.749 & \\
\hline \multirow[t]{3}{*}{2} & \multirow{3}{*}{$\begin{array}{l}\text { Information } \\
\text { reliability }\end{array}$} & Information on arrival and departure & 0.854 & 0.846 \\
\hline & & Information announcement in bus & 0.824 & \\
\hline & & Information sufficiency & 0.757 & \\
\hline \multirow[t]{3}{*}{3} & \multirow{3}{*}{$\begin{array}{l}\text { Luggage } \\
\text { assurance }\end{array}$} & Luggage place & 0.739 & 0.733 \\
\hline & & Carrying luggage & 0.694 & \\
\hline & & Luggage safety & 0.683 & \\
\hline \multirow[t]{4}{*}{4} & \multirow[t]{4}{*}{ Tangibles } & Clean bus & 0.775 & 0.705 \\
\hline & & Good condition seats & 0.606 & \\
\hline & & Comfortable seats & 0.626 & \\
\hline & & Necessary intervals & 0.502 & \\
\hline \multirow[t]{3}{*}{5} & \multirow{3}{*}{$\begin{array}{l}\text { External } \\
\text { tangibles }\end{array}$} & Clean bus stops & 0.503 & 0.720 \\
\hline & & Clean toilets at bus stops & 0.815 & \\
\hline & & Clean drinking water at bus stops & 0.797 & \\
\hline \multirow[t]{4}{*}{6} & \multirow[t]{4}{*}{ Empathy } & Driver courteousness & 0.649 & 0.601 \\
\hline & & Conductor courteousness & 0.685 & \\
\hline & & Eateries & 0.578 & \\
\hline & & Sufficient poles & 0.510 & \\
\hline \multirow[t]{4}{*}{7} & \multirow[t]{4}{*}{ Responsiveness } & Conductor individual attention & 0.619 & 0.772 \\
\hline & & Other staff individual attention & 0.607 & \\
\hline & & Getting reserved seats for special passengers & 0.790 & \\
\hline & & Getting reserved seats for general passengers & 0.790 & \\
\hline \multirow[t]{2}{*}{8} & \multirow{2}{*}{$\begin{array}{l}\text { Women } \\
\text { friendliness }\end{array}$} & Women friendly & 0.897 & 0.860 \\
\hline & & Safety and Security & 0.915 & \\
\hline \multirow[t]{4}{*}{9} & \multirow[t]{4}{*}{ Economic } & Ticket price affordability & 0.711 & 0.683 \\
\hline & & Bus fare satisfaction & 0.860 & \\
\hline & & Service satisfaction for price paid & 0.825 & \\
\hline & & Service to price paid & 0.749 & \\
\hline \multirow[t]{4}{*}{10} & \multirow[t]{4}{*}{ Environmental } & Air pollution & 0.709 & 0.839 \\
\hline & & Noise pollution & 0.842 & \\
\hline & & Abnormal vibration & 0.843 & \\
\hline & & Disturbance due to vibration & 0.845 & \\
\hline
\end{tabular}




\subsection{Determinants of overall satisfaction in the European context}

Table 6 gives the regression results with dependent variable 'overall satisfaction'. The value of $\mathrm{R}$ square is 0.810 which means that about $81 \%$ of the variation in overall satisfaction of the intercity bus transport is explained by the estimated sample regression plane that uses external tangibles, assurance, tangibles, empathy, environment, responsiveness, reliability as the predictors and the model is significant at $1 \%$ level.

The service quality factors of reliability, empathy and tangibles significantly impact the overall satisfaction of the intercity bus service in the European context with the coefficient values of $0.732,0.393$ and 0.308 respectively. Factors such as responsiveness, environmental, assurance and external tangibles do not significantly impact the overall satisfaction although they have emerged as distinct and important service quality factors. This indicates that these factors exist as a part of service quality, but they are not important for passengers when it comes to their overall satisfaction of the service.

Table 6 Model summary (European context)

\begin{tabular}{cccccccc}
\hline Model & $R$ & $R$ square & $\begin{array}{c}\text { Adjusted } \\
\text { R square }\end{array}$ & $\begin{array}{c}\text { SE } \\
\text { (estimate) }\end{array}$ & Durbin-Watson & F value & P value \\
\hline 1 & 0.900 & 0.810 & 0.778 & 0.47534110 & 1.556 & 25.598 & $0.000^{* *}$ \\
\hline \multicolumn{7}{c}{ Variables in the multiple regression analysis - bootstrap } \\
\hline Model & Variables & $B$ & Bias & Std. Error & Sig. (2-tailed) \\
\hline 1 & (Constant) & .003 & -.002 & .071 & 0.966 \\
& Reliability & .732 & -.006 & .081 & $0.000^{* *}$ \\
& Responsiveness & .155 & .000 & .086 & 0.069 \\
& Environmental & -.102 & -.006 & .079 & 0.195 \\
& Empathy & .393 & -.004 & .063 & $0.000^{* *}$ \\
& Tangibles & .308 & -.017 & .066 & $0.000^{* *}$ \\
& Assurance & -.024 & .003 & .074 & 0.733 \\
& External tangibles & .075 & .006 & .064 & 0.247 \\
\hline
\end{tabular}

Note: $* * \mathrm{p}<0.01 ; * \mathrm{p}<0.05$.

\subsection{Determinants of overall satisfaction in the Indian context}

Table 7 gives the regression results for the dependent variable 'overall satisfaction'. The value of $\mathrm{R}$ square is 0.443 means that about $44.3 \%$ of the variation in overall satisfaction of intercity bus transport is explained by the estimated sample regression plane that uses environmental, economic, women friendliness, responsiveness, empathy, external tangibles, tangibles, luggage assurance, information reliability, service time reliability as the predictors and the model is significant at $1 \%$ level. 
Table 7 Model summary (Indian context)

\begin{tabular}{|c|c|c|c|c|c|c|c|c|}
\hline Model & $R$ & R square & $\begin{array}{l}\text { Adjusted } \\
R \text { square }\end{array}$ & $\begin{array}{c}S E \\
\text { (estimate) }\end{array}$ & \multicolumn{2}{|c|}{ Durbin-Watson } & $F$ value & P value \\
\hline 1 & 0.666 & 0.443 & 0.434 & 0.752351 & \multicolumn{2}{|c|}{1.953} & 308 & $0.000 * *$ \\
\hline \multicolumn{9}{|c|}{ Variables in the multiple regression analysis - bootstrap } \\
\hline Model & \multicolumn{2}{|r|}{ Variables } & \multicolumn{2}{|c|}{$B$} & Bias & Std. error & \multicolumn{2}{|c|}{ Sig. (2-tailed) } \\
\hline \multirow[t]{11}{*}{1} & \multicolumn{2}{|c|}{ (Constant) } & \multicolumn{2}{|c|}{$-1.002 \mathrm{E}-013$} & -.001 & .031 & \multicolumn{2}{|r|}{1.000} \\
\hline & \multicolumn{2}{|c|}{ Service time reliability } & \multicolumn{2}{|c|}{.188} & .000 & .035 & \multicolumn{2}{|r|}{$0.000^{* *}$} \\
\hline & \multicolumn{2}{|c|}{ Information reliability } & \multicolumn{2}{|c|}{.196} & -.001 & .034 & \multicolumn{2}{|r|}{$0.000 * *$} \\
\hline & \multicolumn{2}{|c|}{ Luggage assurance } & \multicolumn{2}{|c|}{.259} & .000 & .032 & \multicolumn{2}{|r|}{$0.000 * *$} \\
\hline & \multicolumn{2}{|c|}{ Tangibles } & \multicolumn{2}{|c|}{.274} & .001 & .033 & \multicolumn{2}{|r|}{$0.000 * *$} \\
\hline & \multicolumn{2}{|c|}{ External tangibles } & \multicolumn{2}{|c|}{-.031} & -.002 & .031 & \multicolumn{2}{|r|}{0.322} \\
\hline & \multicolumn{2}{|c|}{ Empathy } & \multicolumn{2}{|c|}{.372} & .001 & .038 & \multicolumn{2}{|r|}{$0.000 * *$} \\
\hline & \multicolumn{2}{|c|}{ Responsiveness } & \multicolumn{2}{|c|}{.257} & .000 & .031 & \multicolumn{2}{|r|}{$0.000 * *$} \\
\hline & \multicolumn{2}{|c|}{ Women friendliness } & \multicolumn{2}{|c|}{.068} & .001 & .032 & \multicolumn{2}{|r|}{$0.032 *$} \\
\hline & \multicolumn{2}{|c|}{ Economic } & & 21 & .000 & .033 & & $0.000 * *$ \\
\hline & Enviro & nmental & & 051 & .000 & .033 & & 0.118 \\
\hline
\end{tabular}

Note: $* * \mathrm{p}<0.01 ; * \mathrm{p}<0.05$

Service quality factors of service time reliability, information reliability, luggage assurance, tangibles, empathy, responsiveness, women friendliness and economic significantly impact the overall satisfaction of the intercity bus service in the Indian context, with the coefficient value of $0.188,0.196,0.259,0.274,0.372,0.257,0.068$ and 0.121 respectively. Factors such as external tangibles and environmental do not emerge significant. This indicates that these factors exist as part of service quality, but they are not important for passengers in the satisfaction of the service.

\section{Additional analysis: impact of technology}

\subsection{Impact of technology on the relationship between transport service quality and overall satisfaction in the European context}

Table 8 gives the results of regression when technology is introduced as an independent variable in the regression equation. The value of $\mathrm{R}$ square is 0.874 means that about $87.4 \%$ of the variation in overall satisfaction of the intercity bus transport is explained by the estimated sample regression plane that uses external tangibles, assurance, tangibles, empathy, environment, responsiveness, reliability and technology as the predictors and the mode 1 is significant at $1 \%$ level. 
Table 8 Model summary (European context)

\begin{tabular}{|c|c|c|c|c|c|c|c|}
\hline Model & $R$ & R square & $\begin{array}{l}\text { Adjusted } \\
R \text { square }\end{array}$ & $\begin{array}{c}S E \\
\text { (estimate) } \\
\end{array}$ & Durbin-Watson & $F$ value & $P$ value \\
\hline 2 & 0.935 & 0.874 & 0.849 & 0.39263645 & 1.556 & 35.397 & $0.000 * *$ \\
\hline \multicolumn{8}{|c|}{ Variables in the multiple regression analysis - bootstrap } \\
\hline Model & \multicolumn{2}{|c|}{ Variables } & $B$ & Bias & Std. error & \multicolumn{2}{|c|}{ Sig. (2-tailed) } \\
\hline \multirow[t]{9}{*}{2} & \multicolumn{2}{|c|}{ (Constant) } & -.004 & -.002 & .060 & \multicolumn{2}{|r|}{0.941} \\
\hline & \multicolumn{2}{|c|}{ Reliability } & .358 & .010 & .108 & \multicolumn{2}{|c|}{$0.003 * *$} \\
\hline & \multicolumn{2}{|c|}{ Responsiveness } & .036 & .003 & .059 & \multicolumn{2}{|r|}{0.511} \\
\hline & \multicolumn{2}{|c|}{ Environment } & -.147 & -.005 & .063 & \multicolumn{2}{|r|}{$0.034^{*}$} \\
\hline & \multicolumn{2}{|c|}{ Empathy } & .291 & .001 & .053 & \multicolumn{2}{|c|}{$0.000^{* *}$} \\
\hline & \multicolumn{2}{|c|}{ Tangibles } & .122 & -.007 & .071 & \multicolumn{2}{|r|}{0.097} \\
\hline & \multicolumn{2}{|c|}{ Assurance } & -.021 & -.004 & .059 & \multicolumn{2}{|r|}{0.725} \\
\hline & \multicolumn{2}{|c|}{ External tangibles } & .128 & .003 & .057 & \multicolumn{2}{|c|}{$0.043 * *$} \\
\hline & \multicolumn{2}{|c|}{ Technology } & .516 & -.018 & .132 & \multicolumn{2}{|c|}{$0.000^{* *}$} \\
\hline
\end{tabular}

Note: ${ }^{* *} \mathrm{p}<0.01 ; * \mathrm{p}<0.05$.

The introduction of technology as a new independent variable brings forth the following changes in the regression results:

a Environmental and external tangibles factors become significant to overall satisfaction. Whereas tangibles factor becomes insignificant (which was significant in the regression model without technology variable).

b The variance ( $\mathrm{R}$ square value) of the model is increased from $81 \%$ to $87.4 \%$.

c Technology variable significantly impact the overall satisfaction of intercity bus transport.

\subsection{Impact of technology on the relationship between transport service quality and overall satisfaction in the Indian context}

Table 9 gives the results of regression when technology is introduced as an independent variable in the regression equation. The value of $R$ square is 0.467 which means that about $46.7 \%$ of the variation in overall satisfaction of intercity bus transport is explained by the estimated sample regression plane that uses environmental, economic, women friendliness, responsiveness, empathy, external tangibles, tangibles, luggage assurance, information reliability, service time reliability and technology as the predictors and the model is significant at $1 \%$ level.

Table 9 represents that along with significant service quality factors from model 1 , the technology factor significantly impacts the overall satisfaction of the intercity bus service with the coefficient value of 0.161 in the Indian context. 
Table 9 Model summary (Indian context)

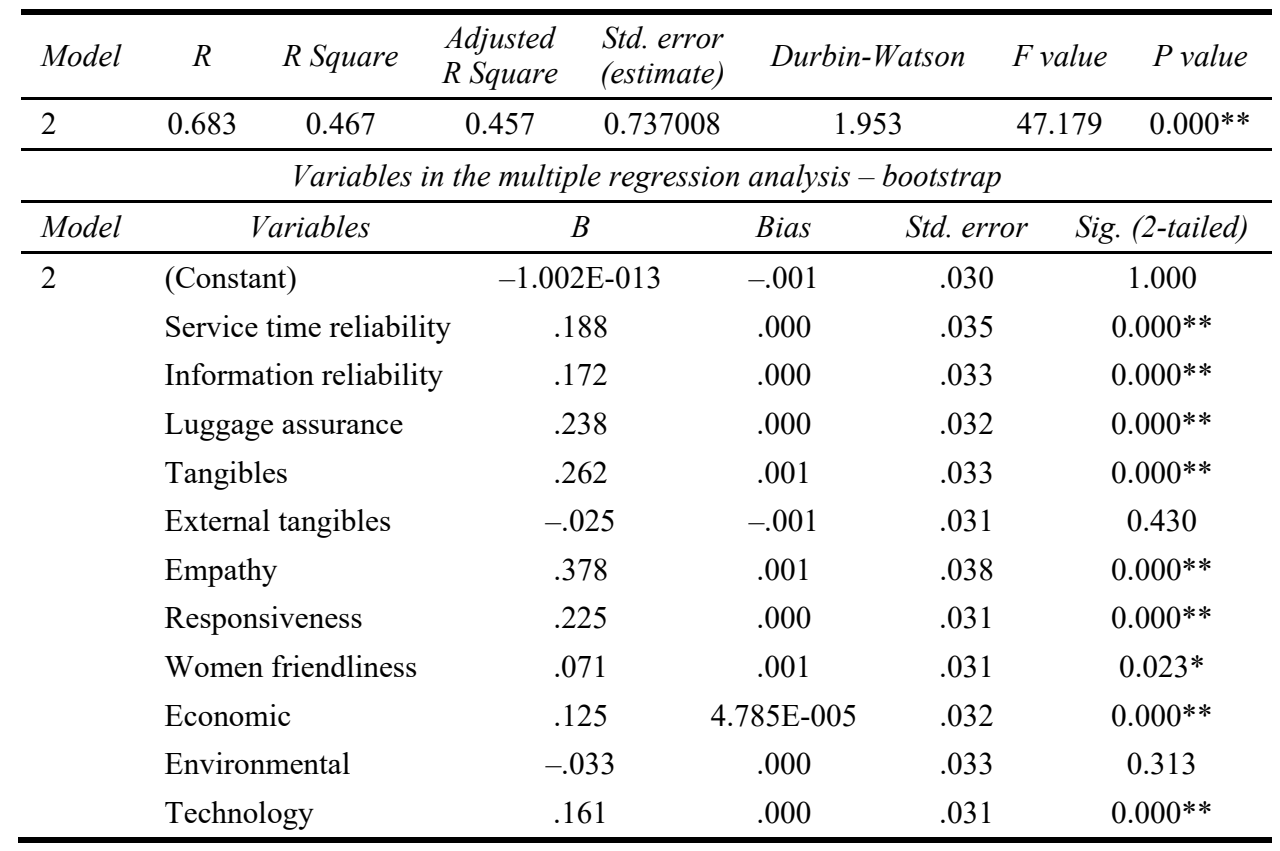

Note: $* * \mathrm{p}<0.01 ; * \mathrm{p}<0.05$.

The introduction of technology as a new independent variable brings forth the following changes in the regression result.

a The variance ( $\mathrm{R}$ square value) of the model is increased from $44.3 \%$ to $46.7 \%$.

b Technology variable significantly impact the overall satisfaction of intercity bus transport.

\section{Discussion}

\subsection{Key findings of the study}

We present a summary of the research objectives, analytical tools and key findings of this international comparative study (Table 10).

\subsection{Main differences between Europe and India and test of the hypotheses}

The results of the study show seven factors emerge as significant for service quality of intercity bus transportation in the European context. The seven factors are reliability (clean bus, employee tidiness, good seats, etc.); responsiveness (intervals, luggage space, etc.); environment (abnormal vibration, air pollution and noise pollution); empathy (information announcement, and individual attention); tangibles (clean toilets and sufficient space); assurance (information on bus and sufficient buses) and external tangibles (drinking water and eateries at the stops). 
Table 10 Research objectives, analysis and key findings of the study

\begin{tabular}{|c|c|c|c|}
\hline Research objective & Research question & Method & Key findings \\
\hline \multirow[t]{4}{*}{$\begin{array}{l}\text { To explore the } \\
\text { service quality } \\
\text { characteristics of } \\
\text { intercity bus } \\
\text { passenger transport } \\
\text { and the } \\
\text { determinants of } \\
\text { overall satisfaction } \\
\text { in the European and } \\
\text { the Indian contexts. }\end{array}$} & $\begin{array}{l}\text { What are the basic } \\
\text { service quality } \\
\text { factors of intercity } \\
\text { bus passenger } \\
\text { transport in the } \\
\text { European context } \\
\text { and the Indian } \\
\text { context? }\end{array}$ & $\begin{array}{l}\text { Factor analysis and } \\
\text { reliability analysis }\end{array}$ & $\begin{array}{l}\text { Reliability, responsiveness, } \\
\text { environmental, empathy, } \\
\text { tangibles, assurance, external } \\
\text { tangibles are the service quality } \\
\text { factors in European context. } \\
\text { Information reliability and time } \\
\text { reliability, luggage assurance, } \\
\text { tangibles (bus related) and external } \\
\text { tangibles (outside bus). Women } \\
\text { friendliness, economic and } \\
\text { environmental are the service } \\
\text { quality factors in Indian context. }\end{array}$ \\
\hline & $\begin{array}{l}\text { What are } \\
\text { determinants of } \\
\text { service quality } \\
\text { satisfaction in } \\
\text { both contexts? }\end{array}$ & $\begin{array}{l}\text { Multiple linear } \\
\text { regression } \\
\text { (hierarchical } \\
\text { regression with } \\
\text { bootstrapping) }\end{array}$ & $\begin{array}{l}\text { Reliability, environment, empathy, } \\
\text { external tangibles and technology } \\
\text { significantly impact the overall } \\
\text { satisfaction in European context. } \\
\text { Service time reliability, } \\
\text { information reliability, luggage } \\
\text { assurance, tangibles, empathy, } \\
\text { responsiveness, women } \\
\text { friendliness and economic factors } \\
\text { significantly impact the overall } \\
\text { satisfaction in Indian context. }\end{array}$ \\
\hline & $\begin{array}{l}\text { What is the change } \\
\text { in the relationship } \\
\text { between service } \\
\text { quality factors } \\
\text { and overall } \\
\text { satisfaction when } \\
\text { technology is } \\
\text { included? }\end{array}$ & $\begin{array}{l}\text { Multiple linear } \\
\text { regression } \\
\text { (hierarchical } \\
\text { regression with } \\
\text { bootstrapping) }\end{array}$ & $\begin{array}{l}\text { In the European context, } \\
\text { environmental and external } \\
\text { tangibles factors become } \\
\text { significant to overall satisfaction. } \\
\text { Whereas tangibles factor becomes } \\
\text { insignificant which was significant } \\
\text { in the regression model without } \\
\text { technology variable. The variance } \\
\text { of the model is increased to } 87.4 \% \\
\text { from } 81 \% \text { when technology } \\
\text { variable is introduced. Technology } \\
\text { variable significantly impact the } \\
\text { overall satisfaction of intercity bus } \\
\text { transport. }\end{array}$ \\
\hline & & & $\begin{array}{l}\text { In the Indian context, variance of } \\
\text { the model is increased to } 46.7 \% \\
\text { from } 44.3 \% \text { when technology } \\
\text { variable is introduced. Technology } \\
\text { variable significantly impact the } \\
\text { overall }\end{array}$ \\
\hline
\end{tabular}

The results of the study show ten factors emerge as significant for service quality of intercity bus transportation in the Indian context. The ten factors are: service time reliability (timely arrival and departure); information reliability (information on arrival and departure, sufficient and adequate announcements); luggage assurance (luggage place, and safety); tangibles (lean bus, good condition seats, comfortable seats); external tangibles (bus stop facilities like cleanliness, toilets and drinking water); empathy (driver and conductor courteousness); responsiveness (conductor and staff giving individual 
attention, getting reserved seats); women-friendliness (women safety and security); economic (ticket price affordability, bus fare, satisfaction for price paid and service to price paid); and environmental (air pollution, noise pollution, abnormal vibration and disturbance due to vibration). From the findings it is evident that there are cultural differences between India and Europe in reliability, responsiveness, luggage assurance and empathy dimensions with respect to intercity bus transport. Hence, the hypothesis (H1) 'institutional and cultural differences exist between Europe and India with respect to the intercity bus transport service quality' is generally supported.

In the European context, the reliability factor such as clean bus, employee tidiness, good seats, women-friendliness, women safety and security, safety precaution information, pleasant interiors, ticket price affordability, clean bus stops, AC and on time departure and arrival significantly impact overall satisfaction. Further, environment factor such as abnormal vibration, air pollution and noise pollution, external tangibles such as clean drinking water and eateries significantly impact overall satisfaction.

In the Indian context, service time reliability, information reliability, luggage assurance, tangibles, empathy, responsiveness, women-friendliness, and economic factors significantly impact overall satisfaction.

The impact of the introduction of technology demonstrates several changes. In the European context it makes environmental and external tangibles factors significant to overall satisfaction and also improves the variance of the model. In the Indian context it improves the variance of the model. Technology factor has a greater influence on overall satisfaction in the European context (87.4\%) when compared to Indian context $(46.7 \%)$ which is evident from its larger shift in variance explained in the model. Service quality factors could explain variance better in the European context $(81 \%)$ when compared to the Indian context (44.3\%). From the findings, it is evident that the service quality impact on overall satisfaction dimensions' differs between Indian and European passengers in external tangibles, environmental, responsiveness, tangibles and assurance dimensions with respect to intercity bus transport. Hence the hypothesis (H2) 'transport service quality will have a positive impact on commuters' perceived service value in Europe and Indian contexts and this positive effect significantly differs' is accepted.

\section{Conclusions}

Based on the above empirical results and research findings of the study, the following observations emerge.

First, compared to the Indian context, European intercity bus passengers are less sensitive to responsiveness such as necessary intervals, employee responsiveness, luggage carrying and luggage place. In India, on the other hand, passengers are cautious about the luggage while travelling in an intercity bus. Luggage assurance emerges as one of the defining and important dimensions of the service quality in India. In the European context, luggage assurance forms only a small part of the reliability and responsiveness of the intercity bus service. This indicates that the preferences vary with cultures which are in accordance with the study of Bremser et al. (2018).

Second, tangibles such as clean toilets and sufficient poles, and assurance factors such as information on bus and sufficient buses are important to European intercity bus passengers. These aspects are an integral part of the service process. The Indian intercity 
bus passengers however are less sensitive to these tangibles such as clean bus stops, clean drinking water and clean toilets.

Third, the reliability dimension of service quality forms an important for intercity bus passengers in both Indian and European context. Reliability dimensions such as service time reliability and information reliability significantly impact the overall satisfaction of the passengers in the Indian context and the European context. In other words, time and frequency are the priority for passengers of both regions. In particular, the reliability dimension of European context is comprehensive which constitutes women-friendliness, economic and service time as part of it whereas in Indian context these dimensions are evaluated individually. This may be because these aspects are considered as the part of the reliable dimension of the service for European passengers than Indian counterpart.

Fourth, notably, the technology interface is essential for passengers of both European and Indian context. Technology significantly impacts and improves the overall satisfaction of the passengers in both the contexts. Technology-based user friendliness and reduced time influences the passengers irrespective of the regions.

Last but not least, environmental factor such as air pollution, noise pollution, abnormal vibration and disturbance due to vibration are not important to Indian intercity bus passengers. This could be of two reasons. One being used to this environment for long time and two exposed to better services with the affordable costs. Environmental dimension has emerged as an important factor of service quality of intercity bus transport in European context. Environmental dimension significantly impacts the overall satisfaction of passengers in European context but not for passenger in the Indian context. Three, lack of awareness of environmental aspects and sustainability practices. This shows that the influence of stakeholder's perception differ across the cultures similar to the study findings of (Lamb and Roundy, 2018).

The study also discusses several limitations of the research strategy which may help scholars in furthering comparative researches on transport service quality and commuters' satisfaction. Firstly, because the sample size of European survey is smaller compared to the sample size of Indian survey, and only France, Netherlands and Germany are selected for the European survey, our comparative empirical findings are generally limited to these sample countries. Second, because there is a large difference in sample size between the sample contexts, extensive comparative analysis using adequate empirical tools such as structural equation modelling is undone. Though, it should be noted that for producing some meaningful comparative results, the study applies a bootstrapping with 3,000 samples in both contexts. However, since the sample size of Indian survey is relatively larger than the sample size of earlier studies in the Indian context (Randheer and Al-Motawa, 2011), main results are consistent and more applicable to emerging countries. Future studies are suggested to generate a large sample size in each context and conduct extensive international comparative researches between developed and emerging countries, which may have several implications for improving intercity transport service quality and passengers' perceived service value.

Appendices/Supplementary materials are available on request by emailing the corresponding author. 


\section{References}

Aghdaie, S.F.A. and Faghani, F. (2012) 'Mobile banking service quality and customer satisfaction (application of SERVQUAL model)', International Journal of Management and Business Research, Vol. 2, No. 4, pp.351-361.

Allard, R.F. and Moura, F. (2018) 'Effect of transport transfer quality on intercity passenger mode choice', Transportation Research Part A: Policy and Practice, March, Vol. 109, pp.89-107.

Andaleeb, S.S., Haq, M. and Ahmed, R.I. (2007) 'Reforming inner city bus transportation in a developing country: a passenger-driven model', Journal of Public Transportation, Vol. 10, No. 1, p.1.

Anderson, E.W., Fornell, C. and Mazvancheryl, S.K. (2004) 'Customer satisfaction and shareholder value', Journal of Marketing, Vol. 68, No. 4, pp.172-185.

Bak, M., Borkowski, P. and Pawlowska, B. (2012) 'Passenger transport interconnectivity as a stimulator of sustainable transport development in the European Union', Sustainable Transport, pp.21-39, Springer, Berlin, Heidelberg.

Bakti, I.G.M.Y. and Sumaedi, S. (2015) 'P-TRANSQUAL: a service quality model of public land transport services', International Journal of Quality \& Reliability Management, Vol. 32, No. 6, pp.534-558.

Beerli, A., Martin, J.D. and Quintana, A. (2004) 'A model of customer loyalty in the retail banking market', European Journal of Marketing, Vol. 38, Nos. 1-2, pp.253-275.

Bitner, M.J. and Hubbert, A.R. (1994) 'Service quality: new directions in theory and practice', in Rust, R.T. and Oliver, R. (Eds.): Encounter Satisfaction versus Overall Satisfaction versus Quality, p.77, Sage Publications, Thousand Oaks, California.

Bremser, K., Walter, N. and Goehlich, V. (2018) 'A comparative study on glocal commercial advertisement perceptions - British and French viewers' responses to Red Bull', International Journal of Comparative Management, Vol. 1, No. 4, pp.333-354.

Carreira, R., Patrício, L., Jorge, R.N., Magee, C. and Hommes, Q.V.E. (2013) 'Towards a holistic approach to the travel experience: a qualitative study of bus transportation', Transport Policy, Vol. 25, pp.233-243.

Chang, Y.H. and Yeh, C.H. (2017) 'Corporate social responsibility and customer loyalty in intercity bus services', Transport Policy, Vol. 59, pp.38-45.

Chen, C. F. (2008) 'Investigating structural relationships between service quality, perceived value, satisfaction, and behavioral intentions for air passengers: evidence from Taiwan', Transportation Research Part A: Policy and Practice, Vol. 42, No. 4, pp.709-717.

Chica-Olmo, J., Gachs-Sánchez, H. and Lizarraga, C. (2018) 'Route effect on the perception of public transport services quality', Transport Policy, Vol. 67, pp.40-48.

Chou, J.S. and Kim, C. (2009) 'A structural equation analysis of the QSL relationship with passenger riding experience on high speed rail: An empirical study of Taiwan and Korea', Expert Systems with Applications, Vol. 36, No. 3, pp.6945-6955.

Clean Air Asia Center (2012) Development of Clean Fleet Bus Program for India, November.

Clemes, M.D., Gan, C., Kao, T.H. and Choong, M. (2008) 'An empirical analysis of customer satisfaction in international air travel', Innovative Marketing, Vol. 4, No. 2, pp.50-62.

Cronin Jr., J.J. and Taylor, S.A. (1992) 'Measuring service quality: a reexamination and extension', Journal of Marketing, Vol. 56, No. 3, pp.55-68.

Das, S. and Pandit, D. (2016) 'Qualitative assessment of public facilities: the 'public bus', The TQM Journal, Vol. 28, No. 2, pp.275-294.

De Oña, J., de Oña, R., Eboli, L. and Mazzulla, G. (2013) 'Perceived service quality in bus transit service: a structural equation approach', Transport Policy, Vol. 29, pp.219-226.

Eboli, L. and Mazzulla, G. (2007) 'Service quality attributes affecting customer satisfaction for bus transit', Journal of Public Transportation, Vol. 10, No. 3, p.2. 
Echeverry, J.C., Ibanez, A.M., Moya, A., Hillon, L.C., Cárdenas, M. and Gómez-Lobo, A. (2005) 'The economics of TransMilenio, a mass transit system for Bogotá [with comments]', Economía, Vol. 5, No. 2, pp.151-196.

Estache, A. and Gómez-Lobo, A. (2005) 'Limits to competition in urban bus services in developing countries', Transport Reviews, Vol. 25, No. 2, pp.139-158.

Fageda, X. and Sansano, S. (2018) 'Factors influencing prices and frequencies in the interurban bus market: evidence from Europe', Transportation Research Part A: Policy and Practice, November, Vol. 111, pp.266-276 [online] https://doi.org/10.1016/j.tra.2018.03.022.

Finn, B. and Mulley, C. (2011) 'Urban bus services in developing countries and countries in transition: a framework for regulatory and institutional developments', Journal of Public Transportation, Vol. 14, No. 4, p.5.

Fornell, C. (1992) 'A national customer satisfaction barometer: the Swedish experience', The Journal of Marketing, Vol. 56, No. 1, pp.6-21.

Fravel, F.D. (2003) 'Intercity bus links: moving into new territory', TR News, No. 225.

Gagliano, K.B. and Hathcote, J. (1994) 'Customer expectations and perceptions of service quality in retail apparel specialty stores', Journal of Services Marketing, Vol. 8, No. 1, pp.60-69.

Hayashi, Y., Morichi, S., Oum, T.H. and Rothengatter, W. (Eds.) (2014) Intercity Transport and Climate Change: Strategies for Reducing the Carbon Footprint, Vol. 15, Springer.

Herrmann, A., Huber, F. and Braunstein, C. (2000) 'Market-driven product and service design: bridging the gap between customer needs, quality management, and customer satisfaction', International Journal of Production Economics, Vol. 66, No. 1, pp.77-96.

Horovitz, J. (1986) 'La non-qualité non-qualité tue', Harvard-L'Expansion, Summer, No. 41, pp. $53-61$.

Hu, K.C. and Jen, W. (2006) 'Passengers' perceived service quality of city buses in Taipei: scale development and measurement', Transport Reviews, Vol. 26, No. 5, pp.645-662.

International Labour Organization (ILO) (2015) Priority Safety and Health Issues in the Road Transport Sector [online] https://www.ilo.org/sector/Resources/publications/WCMS 400598/ lang--en/index.htm.

Irtema, H.I.M., Ismail, A., Borhan, M.N., Das, A.M. and Alshetwi, A.B. (2018) 'Case study of the behavioural intentions of public transportation passengers in Kuala Lumpur', Case Studies on Transport Policy, Vol. 6, No. 4, pp.462-474.

Kaiser, H.F. (1974) ‘An index of factorial simplicity’, Psychometrika, Vol. 39, No. 1, pp.31-36.

Kaushik, S. (2015) Gujarat Inter-city Transport Regulatory Authority, pp.1-16 [online] http://www.cuts-ccier.org/CREW/pdf/Gujarat_Intercity_Transport_Regulatory_Authority.pdf.

Khurshid, R., Naeem, H., Ejaz, S., Mukhtar, F. and Batool, T. (2012) 'Service quality and customer satisfaction in public transport sector of Pakistan: an empirical study', International Journal of Economics and Management Sciences, Vol. 1, No. 9, pp.24-30.

Lai, W.T. and Chen, C.F. (2011) 'Behavioral intentions of public transit passengers - the roles of service quality, perceived value, satisfaction and involvement', Transport Policy, Vol. 18, No. 2, pp.318-325.

Lamb, N.H. and Roundy, P.T. (2018) 'Institutional, stakeholder, and cultural influences on corporate social performance: an institution-based view', International Journal of Comparative Management, Vol. 1, No. 1, pp.4-18.

Lardinois, C. (1989) 'Simulation, gaming and training in a competitive, multimodal, multicompany, intercity passenger-transportation environment', The Journal of the Operational Research Society, October, Vol. 40, No. 10, pp.849-861.

Leblanc, G. and Nguyen, N. (1997) 'Searching for excellence in business education: an exploratory study of customer impressions of service quality', International Journal of Educational Management, Vol. 11, No. 2, pp.72-79. 
Leong, L.Y., Hew, T.S., Lee, V.H. and Ooi, K.B. (2015) 'An SEM-artificial-neural-network analysis of the relationships between SERVPERF, customer satisfaction and loyalty among low-cost and full-service airline', Expert Systems with Applications, Vol. 42, No. 19, pp.6620-6634.

Lu, J.L. and Ling, F.I. (2008) 'Cross-cultural perspectives regarding service quality and satisfaction in Chinese cross-strait airlines', Journal of Air Transport Management, Vol. 14, No. 1, pp.16-19.

Mahmoud, M. and Hine, J. (2016) 'Measuring the influence of bus service quality on the perception of users', Transportation Planning and Technology, Vol. 39, No. 3, pp.284-299.

Nagata, H., Satoh, Y., Gerrard, S. and Kytömäki, P. (2004) 'The dimensions that construct the evaluation of service quality in academic libraries', Performance Measurement and Metrics, Vol. 5, No. 2, pp.53-65.

Namboodiri, U. (2007) State Policies Affecting Competition: Passenger Road Transportation Sector, April, National Council of Applied Economic Research [online] http://www.cci.gov.in/ sites/default/files/2statepolicesaffecting_20080508111218.pdf (accessed 15 July 2018).

Parasuraman, A., Zeithaml, V.A. and Berry, L.L. (1985) 'A conceptual model of service quality and its implications for future research', Journal of Marketing, Vol. 49, No. 4, pp.41-50.

Parasuraman, A., Zeithaml, V.A. and Berry, L.L. (1988) 'Servqual: a multiple-item scale for measuring consumer perc.', Journal of Retailing, Vol. 64, No. 1, p.12.

Ponnaluri, R.V. (2011) 'Sustainable bus rapid transit initiatives in India: the role of decisive leadership and strong institutions', Transport Policy, Vol. 18, No. 1, pp.269-275.

Ponrahono, Z., Bachok, S., Ibrahim, M. and Osman, M.M. (2016) 'Assessing passengers' satisfaction level on bus services in selected urban and rural centres of Peninsular Malaysia', Procedia - Social and Behavioral Sciences, Vol. 222, pp.837-844.

Randheer, K. and Al-Motawa, A.A. (2011) 'Measuring commuters' perception on service quality using SERVQUAL in public transportation', International Journal of Marketing Studies, Vol. 3, No. 1, p.21.

Rohani, M.M., Wijeyesekera, D.C. and Karim, A.T.A. (2013) 'Bus operation, quality service and the role of bus provider and driver', Procedia Engineering, Vol. 53, pp.167-178.

Rojo, M., Gonzalo-Orden, H., dell'Olio, L. and Ibeas, Á. (2012) 'Relationship between service quality and demand for inter-urban buses', Transportation Research Part A: Policy and Practice, Vol. 46, No. 10, pp.1716-1729.

Sam, E.F., Hamidu, O. and Daniels, S. (2018) 'SERVQUAL analysis of public bus transport services in Kumasi metropolis, Ghana: core user perspectives', Case Studies on Transport Policy, Vol. 6, No. 1, pp.25-31.

Sekulić, D., Rusov, S., Dedović, V., Šalinić, S., Mladenović, D. and Ivković, I. (2018) 'Analysis of bus users' vibration exposure time', International Journal of Industrial Ergonomics, Vol. 65, pp.26-35.

Siddiqi, K.O. (2011) 'Interrelations between service quality attributes, customer satisfaction and customer loyalty in the retail banking sector in Bangladesh', International Journal of Business and Management, Vol. 6, No. 3, p.12.

Şimşekoğlu, Ö., Nordfjærn, T. and Rundmo, T. (2015) 'The role of attitudes, transport priorities, and car use habit for travel mode use and intentions to use public transportation in an urban Norwegian public', Transport Policy, Vol. 42, pp.113-120.

Soloviev, A. (2015) Bus and Coach Transportation: Buses can Compete with Air and Rail Transportation [online] https://www.theseus.fi/handle/10024/91457 (accessed 15 January 2018).

Steg, L. and Gifford, R. (2005) 'Sustainable transportation and quality of life', Journal of Transport Geography, Vol. 13, No. 1, pp.59-69. 
Susilo, Y.O., Joewono, T.B. and Santosa, W. (2010) 'An exploration of public transport users' attitudes and preferences towards various policies in Indonesia', Journal of the Eastern Asia Society for Transportation Studies, Vol. 8, pp.1230-1244.

Susniené, D. (2012) 'Quality approach to the sustainability of public transport', Transport, Vol. 27, No. 1, pp.102-110.

Tyrinopoulos, Y. and Antoniou, C. (2008) 'Public transit user satisfaction: variability and policy implications', Transport Policy, Vol. 15, No. 4, pp.260-272.

Wen, C.H., Lan, L. and Cheng, H.L. (2005) 'Structural equation modeling to determine passenger loyalty toward intercity bus services', Transportation Research Record: Journal of the Transportation Research Board, Vol. 1927, No. 1, pp.249-255.

Winston, C. (1985) 'Conceptual developments in the economics of transportation: an interpretive survey', Journal of Economic Literature, Vol. 23, No. 1, pp.57-94.

Yaya, L.H.P., Fortià, M.F., Canals, C.S. and Marimon, F. (2015) 'Service quality assessment of public transport and the implication role of demographic characteristics', Public Transport, Vol. 7, No. 3, pp.409-428.

Zeithaml, V.A. (1988) 'Consumer perceptions of price, quality, and value: a means-end model and synthesis of evidence', Journal of Marketing, Vol. 52, No. 3, pp.2-22. 